\title{
小断面シールド掘削を対象とした集中自動制御システム の設計とその試験結果 \\ DESIGN OF COMPUTER CONTROLLED SYSTEM FOR SMALL DIAMETER SHIELD METHOD AND RESULT OF ITS EXPERIMENTS
}

\author{
山岸康利* ・ 鶴田秀典**・杉本禎男*** • 阿南修平**** \\ By Yasutoshi YAMAGISHI, Hidenori TSURUDA, Sadao SUGIMOTO \\ and Shuhei ANAN
}

\begin{abstract}
A shield tunneling method has been applied more year by year according to society's demands. NTT requires a long and small diameter tunnel for installation of fiber cables.

To construct a long tunnel with $1200 \mathrm{~mm}$ inside diameter, new tunneling system different from conventional ones had to be developed. Fully automated tunneling and cast in situ lining system using quick setting resin mortar have been studied since 1975.

New tunneling method controlled by computer was developed in 1984 . Field trial results show that constructed tunnels are reliable to install telecommunication cables.
\end{abstract}

\section{まえがき}

電気通信ケーブルを収容する管路設備は, 道路下に埋 設されており，その築造は通常道路表面を掘削し管路等 を掘削溝内に布設する方法で行われている.しかしなが ら, 地下埋設物の輻輳化に伴い開削工法による管路工事 の困難性が高まり, 非開削工法が増加してきている. そ こで, 市街地での管路布設工事を効率的に行らために内 径 $1200 \mathrm{~mm}$ の小断面シールド工法の開発を行ってきた. 本工法の開発にあたり，第一段階として掘進長 $150 \mathrm{~m}$, ヒューム管をライニングとし, 機械的制御による小断面 シールド工法 (M-1) を研究し実用化を図ってきたが, 本 工法では掘進長,曲線施工, 適用土質等に制限があるとこ

* 正会員 日本電信電話(株)茨城電気通信研究所 通信土 木研究室長

（宁319-11／茨城県那珂郡東海村白方白根 162）

** 正会員 日本電信電話(株) 登戸電報電話局長 （干214/神奈川県川崎市多摩区登戸 1754-1）

*** 正会員 日本電信電話(株)茨城電気通信研究所 研究専 門調査員

（开319-11/茨城県那珂郡東海村白方白根 162）

**** 正会員 工修 日本電信電話(株)図際企画室調查員 (同 上)
ろから適用領域が限られるといら問題点が生じてきた. そこで第二段階として, 都市部における立坑用地の制約 条件や中継間隔の長い光ファイバーケーブルの導入に対 応するため, 道路線形なりに長距離, 曲線施工が可能で かつ涌水を伴う自立性, 非自立性の両地盤に対応できる シールド機の開発を行らこととし, 小断面シールド工法 (D 1200-M 2, 以下 M-2 工法と言5) の開発に着手した. M-2 工法の開発目標を達成するためには, トンネル坑内が狭 く, 掘削長が長距離となるために坑内作業を無人化する 必要が生じ, コンピューターによる掘削作業の集中制御 技術が是非とも必要になってきた。 M-2 工法に要求さ れる制御技術を整理すると以下のとおりである。

(1) 湧水を伴う自立性, 非自立性地盤での掘削, 排 土が可能な装置とセンサーを含めた制御技術や計画線 に十分な追随性機能を持たせるための方向制御技術.

(2) 従来のヒューム管推進工法とは全く異なったシ ールド機内でのライニング築造技術と制御方法.

(3) 掘削土, ライニング材料のトンネル坑内での運 搬が可能な自動運搬技術.

(4) 全システムを制御する集中制御システム. 以上の制御技術を開発するために多くの基礎検討を繰り 返し，以下に列挙する種々の方策を採用寸ることとした. 
(1) 掘削状況監視センサーによる自動掘削方式

(2) ジャイロ計測によるシールド機姿勢に基づく使 用ジャッキ自動選択方式

(3) 早強性レジン材料を用いた現場打設ライニング 方式

(4) 無軌道, 自走式坑内運搬方式

(5) 制御機能を集中したユニット式運転室からの自 動遠隔制御方式

M-2 システムでは，各工程の制御に必要なセンサー， アクチュエーター, 装置類を開発するとともに, これら をコントロールする制御システムを検討し，それらを実 際に試作した。 また， M-2 システムの機能を確認する ために，実際の地盤で 2 度にわたり試験工事を実施 し た. その結果，集中制御システムを採用した M-2 工法 は長距離，曲線施工におけるトンネル築造制御技術とし て十分満足するものであり，実用に供しうるものである ことが判明した。

本工法はトンネル掘削の主要工程である掘削，ライニ ング，材料等の搬入，搬出を完全に自動化するものであ り，作業のメカトロニクス化を図ったものである、これ により, 従来から行われてきた技術者の勘と経験に頼る 方法から大きく進歩するとともに，長距離で曲線部の卜 ンネル掘削の自動化が可能となった.

本文は，M-2 工法の集中制御システムの設計内容と 試験工事の制御結果について述べるものである.

\section{1. 開発方針}

内径 $1200 \mathrm{~mm}$ の小口径トンネルにおいて長距離・曲 線施工・適用土質の拡大を実現するにあたって，以下の ような開発目標を設定した.

(1) 適用土質として涌水を含んだ砂，砂碗，粘性土 地盤

(2) 掘進長は都市での適用を考慮して最大 $500 \mathrm{~m}$ とする

(3) 曲率半径は 道路線形をふまえて $200 \mathrm{~m}$ の曲線 掘削を考える

(4) 掘削深度は埋設物の下越しを考虑して $10 \mathrm{~m}$ 以内

(5) トンネル内径は通信 ケーブルの管路を最大 40 条として $1200 \mathrm{~mm}$ に設定 上記開発目標を実現するために，トンネル坑内作業の 自動化に適したシールドシステムと各種工程のコンピュ ーター制御による集中制御システムの設計方針を定めた

\section{（1） シールドシステム}

従来のシールド機構造をそのまま小断面シールド機に 適用することは空間が限られているために困難と判断し
種々の工程を自動化するためにシールド工法のシステム 全般にわたり検討を行い以下のような設計方針を定めた

(1) 収容機器が多いため内径 $1200 \mathrm{~mm}$ では長いシ ールド機となり方向制御特性に問題を生じるため多分 割構造とする.

(2) 油圧配管を集中し，装置の小型化をはかり油圧 駆動源をスキンプレートに直接固定する方式とし中央 部のスペースを確保すると共にオイルタンクの放熱を 効果的なものとする.

(3) 制御機器の保護, 配線の集約のため電気機器, 制御機器は一個所に集中させ，機内スペース確保のた め, 機能別に分割しスキンプレート内壁に固定設置す る.

(4) 掘削方式においては，涌水を含む軟弱な地盤の 土質変化に対応するため間欠運転機能を有した土砂取 り込み装置を前面密閉型バルクヘッドに装着する。

(5) トンネル内径が一般のシールドトンネルに比較 して非常に小さいため方向制御に必要な計測はジャイ ロスコープで行う。

(6) ライニング方式においては, 長距離, 曲線掘進 のため現場打設によるライニングとしシールド機内最 後部にライニング部を設置する.

(7) 狭いトンネル坑内での掘削土，ライニング材料 の搬出入は坑内無人化のためレール布設や手動運転を 不用とする自動走行式坑内運搬車により行う.

\section{（2）集中制御システム}

各工程の自動化に適したシールドシステムをコンピュ ーターにより集中制御するため, 制御システムおよび制 御アルゴリズムの設計方針を次のように定めた。

(a) 制御システム：システムの運用において最適な 制御システムとするため以下のようにシステム設計を行 った.

(1) 一人のオペレーターにより同一場所で全システ ムを操作できる方式とする.

(2) 1 つのスイッチ操作で 1 つの工程 (擗削等) が起 動されるように，操作を容易にするとともに，CRT や指示計 パネルランプ等により状態把握を容易にし て，オペレーターのバックアップを行う．

(3) 操作卓において各種機器の動作点検が可能な機 能を持たせる。

(4) センター装置は一ユニットとし，立坑内外どこ でも設置可能なものとする.

(5) 制御室のコンピューターや CRT 等の制御装置 の耐環境性を持たせるため, 操作室側とセンター装置 側は隔壁により分離し, 空調により対処する.

（6) 制御プログラムはすべてセンターコンピュータ 
一に收容することにより維持管理を容易にする.

(7) プログラムには，オペレーターの誤動作を防止 するため, インターロック機能を施す.

(8) 施工条件や機器の部分故障にフレキシブルに対 処し，システムダウンを防ぐためプログラムに圥長性 を持たせる。

(9) 端末機器は機内配線の複雑化を避けるため, デ ジタル化しコンパクト化,インテリジェント化を行う.

(10) シールド機内の狭い空間環境において, 制御機 器, センサー, ケーブル等の保守, 点検の容易なシス テムとする.

(11) 坑内ケーブルを少なくするため，制御信号はデ ジタル化し，伝送路は一本の同軸ケーブルとする.

（b）制御アルゴリズム：従来人間の判断により運転 していた掘削，ライニング，材料等の運搬をコンピュー ターにより自動制御するために基本的なアルゴリズムを 以下のように設定した。

(1) 掘削については, 砂, 粘土, 砂砣, 涌水等に適 用でき，カッターのかみこみ等による掘進不能を防止 できるものとする.

(2) ライニングについては，モルタル特性が変化し ても一定品質で一定量のレジンモルタルが打設でき, 打設時における異常状態に際しては打設機の保護処理 ができるものとする.

(3) 運搬車については, 一定の速度, 姿勢角度を保 持しながら自動走行を行い, 所定の位置に自動停止で き, 安全対策としてシステム外から非常停止が可能な ものとする.

\section{2. シールドシステムの設計}

シールドシステムはトンネル勧造プロセスの完全なる 自動化を目的として，掘削地盤に最適な掘削方法および 計画線に沿った方向制御, 早強性材料によるシールド機 内での自動現場打設ライニング方法, 無軌道で自走可能 な坑内運搬車によるライニング材料の運搬, 供給および 掘削土の搬出ができるシールドシステムの開発を目指し たものである.

\section{（1） シールド機の構成}

シールド機本体は 4 分割構造になっており，それぞれ は先端で土を掘削する掘削部, シールド機系の制御機器 を取りつけた制御部，駆動源である油圧発生装置を取り つけたパワーユニット部，レジンライニングを筑造する ライニング部の 4 つである. 図一1 にシールド機の概要 を示す。
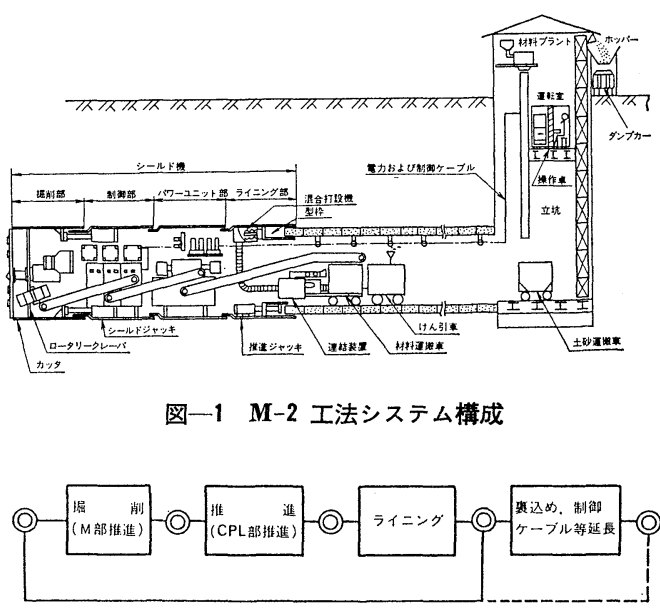

(C)：坑内運影本入出坑

図一2 施工方法

\section{（2）施エプロセス}

レジントンネルは $50 \mathrm{~cm}$ ごとのシールド機の前進お よびライニングの繰り返しにより築造できるように設計 されている. 図一2 に施工プロセスを示す.

(a) 掘削：シールドジャッキを伸ばしながらカッタ 一により土を切削し, 排土装置により機内に取り込み, ベルトコンベアにのせライニング部後方で土砂運搬車に 積み込みトンネル坑外一搬出する，掘削中は排土装置， シールドジャッキの ON-OFFにより取り込み量を管理 する掘削制御を行うとともに, シールドジャッキ等の選 択により掘削部の方向制御を行い，あらかじめ投入した 計画線に自動的に追随させる.

（b）推進：掘削後,シールドジャッキを縮めてから 推進ジャッキを伸ばし制御部, パワーニニット部, ライ ニング部を前進させ, 次に推進ジャッキを縮め, 型枠内 をレジンモルタル充填可能な状態にする.

（c） ライニング：材料運搬車により，レジンモルタ ル材料をトンネル坑内に搬入し，ライニング部の固定連 結装置と材料運搬車の先端にある連結機を自動的に接続 し，ライニング部に固定した混合打設機に材料を空気圧 送する．混合打設機内では，硬化液とレジンモルタルを 混合し型枠内に押し出すが, 硬化液とレジンモルタルの 重量比が一定となるように送給制御を行うと共に充填量 の管理を行う.

（d） 裹込め：地山と筑造されたレジントンネルとの 空嚐に材料運搬車により搬入された裹込材を充填する.

\section{（3）制御装置とのインタフェース}

各アクチュエーターと制御装置とのインタフェースは 以下の機構によりコンピューターからの制御信号でアク 
チュエーターを動作させることができる.

(1) ミニチュアリレーは動作電流が小さいので制御 信号に対応したトランジスターアンプで直接作動する

(2) 油圧は電動モーターを用いて発生させている が, 電動モータはミニチュアリレーで動作するマグネ ットスイッチにより起動, 停止する.

(3) シールド機は油圧駆動方式を採用しておりアク チュエーターは電磁弁により作動する.

\section{3. 制御システムの設計}

制御システムの設計にあたっては，システム全体の集 中制御と各工程ごとの制御について以下のように設計を 行った.

\section{（1）集中制御}

（a）ソフトゥエア：システム全体を起動させるため には, 各センサー, アクチュエーター等の状態を常に監 視し必要のつど制御信号を送信し制御を行う。このため にプログラムの複雑化をさけ, 製作・保守を容易にする とともに，ミニコンを最適な方法により使用する必要が ありソフトウエアの構成を, タスク化されたプログラム と共通データをストアするコモンテーブルに区分した. またこれらのソフトウェアの作成にあたり, 次のことに 留意した.

(1) 制御信号はすべてコンピューターにより管理す るとともに誤動作危険防止のため, ソフトウエアによ るインターロック機能を持たせる.

(2) 制御工程中の機器動作を直接または間接的に常 時監視し, 必要のつど異常処理, アラーム通報を行い オペレーターをバックアップする.

(3) 土質条件，レジンモルタルの状態に対応した制 御を可能とするため, 各種パラメーターの設定スイッ チを設けるとともに，キーボードから制御定数変更可 能なよらにプログラムにフレキシビリテイを持たせる

(4) オペレーターによる安全確認の必要な制御工程 はディスプレイによるガイドメッセージに対し， 2 段 階の確認動作により対応する.

(5) パワーユニット，シールドジャッキ伸縮等を単一 の半自動スイッチで起動させ, 必要のつど全自動制御 から手動操作も可能なものとする.

(6)各工程を自動制御で行う直前に装㯰類の状況を確 認するため点検工程を設ける.

(7)各端末からのデータの処理は, 各端末に設置され ているマイコンにより行い, センターミニコンの負荷 を軽減させる。

図一3 にソフトウエアの構成を示す. （b）ハードウェア：制御装置の

設計に際しては, 次の 3 つの機能に ついてそれぞれ列挙する内容を考慮 した.

(1) 制御機能

i ） センサー信号の統一を図 り, $\mathrm{A} / \mathrm{D}$ 変換装置の共通化を 行うため, センサー電源, 出 力電圧を同一とする.

ii） センターコンピューターヘ の入力信号は, インタフェー

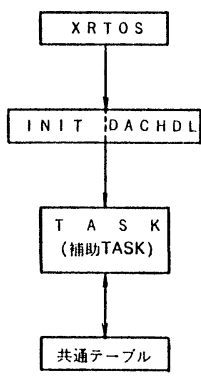

图一3 ソフトゥエ ア構成 ス装置を介して入出力を行らが，信号系統はシー ルド機系, 運搬車系, 操作卓系, 立坑監視系の 4 つに分け信号系統の明確化を図る.

iii） センター装置に信号モニターと個別の機器に対 応したテストスイッチを設置し，故障個所の判別 を容易なものとする.

\section{(2) 伝達機能}

i ）信号伝送はトンネル内ケーブルの小型化，伝送 距離および而雑音性を考慮してデジタル信号伝送 方式とする.

ii）伝送路としては，シールド系には同軸ケーブル とし，坑内運搬車は移動するため無線とする.

(3) 端末機能

i ）保守点検を容易にするため, 機内配線を集約す る分岐ボックスを各部に設けるとともに，制御端 末には信号モニターを設置し, 動作状態の目視点 検を可能なものとする.

ii）坑内機器の耐環境性については, 高価格化, 大 型化を避けるため, 防滴構造により対応する.

図一4 は集中制御システムの構成を示したものである 本システムにおけるハードウェアは, シールド機内の シールド機端末装置, 自走車に設置されている自走車端 末装置, 運転室センター装置側のミニコン，シールド機 入出力装置, 自走車入出力装置, 立坑入出力装置, 操作 卓入出力装置, シールド機伝送装置, 自走東系伀送装 置, 無線供用分配装置, シールド系 MODEM 等から構 成されている.

また運転室操作卓側には，シールド機内等の状沉を監 視するモニター TV, 各工程の状況をオペレーターに示 すディスプレイ, 表示部, ミニコンに制御入力を行ら操 作卓, キーボードさらにデータの出力としてプリンター 保守点検のためのスイッチボックス等により構成されて いる.

本システムにおけるシールド機系の監視信号, 制御信 号の流れを図一5 に示す.

（c）センサ技術：M-2 システムの 制御や 施工状況 


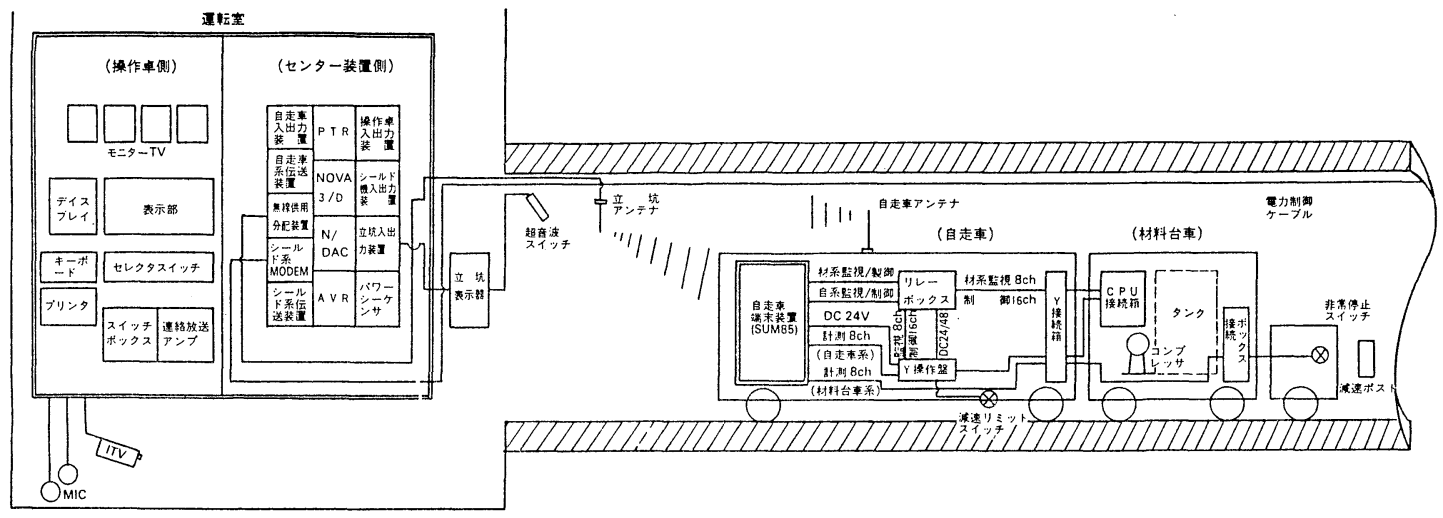

( $\mathrm{L}$ 部) ( $\mathrm{P}$ 部)

(c 部)

( $M$ 部)

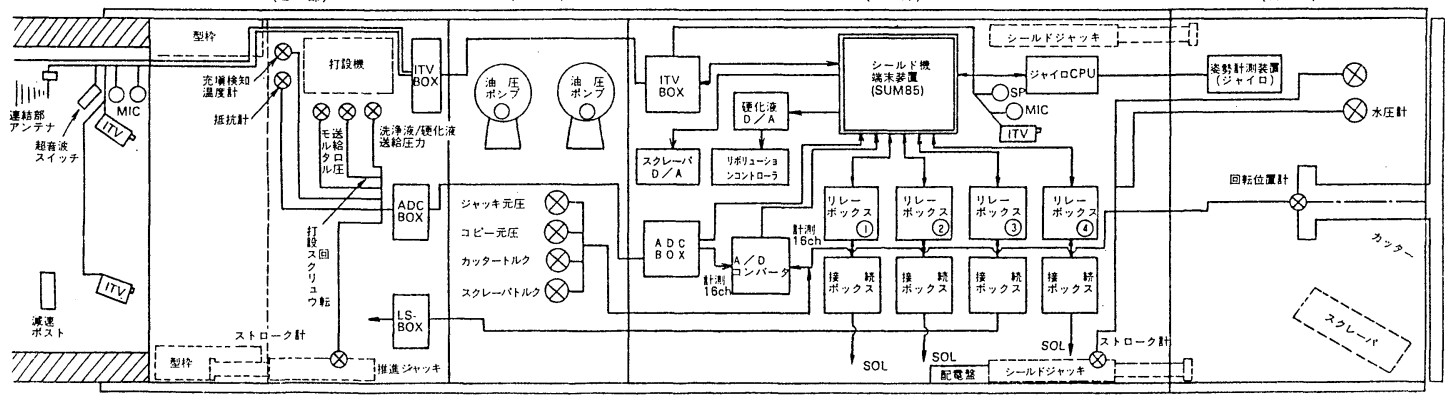

図一4集中制御システム構成

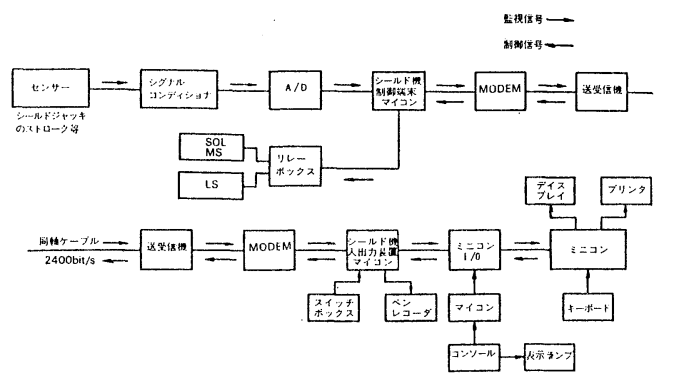

図一5 シールド機系（例）

の把握を自動化するために, 次に列挙する各種センサを 開発した.

(1) 掘削土砂の弱い押しつけ力 $(1 \sim 2 \mathrm{~kg})$ で作動する バネ機構式掘削チャンバー内土砂レベル計

(2) カッター軸に直接取付可能で, 回転角度入力に 対し出力電圧を直線的に変化するコピーカッター回転 位置計

(3) ストローク長最大 $1000 \mathrm{~mm}$ 精度 $\pm 1 \mathrm{~mm}$ で直 接検出する $\phi 0.3 \mathrm{~mm}$ のステンレスワイヤー巻き取り 式ジャッキストローク計

(4) ヒーターで検出温度を一定に保ち，レジンモル タルが接触した時の微小な温度降下 $\left(0.2 \sim 0.4^{\circ} \mathrm{C} / \mathrm{s}\right)$ を検 出する型枠内レジンモルタル充填レベル計

(5) 信号出力範囲を $\pm 10 \mathrm{~V}$ で統一可能な歪ゲージ
式変換器用シグナルコンディショナー

(6) ロードセルの筐体内にシグナルコンディショナ 一を内臟し, 耐環境性を高めたアンプ内藏型ロードセ ル

(7) ジャイロスコープおよびアクセロメーターの出 力を直接演算処理を行らマイコン実装式姿勢計測装置

\section{（2）掘進工程}

掘進工程におけるアルゴリズムと制御方法についてま とめると以下のとおりである.

(a) アルゴリズム：シールド機先端のカッターによ り地山を掘削する場合, 掘削スピードや排土量を管理し なければ地表面の沈下や，シールド機前面の閉塞，シー ルド機内への土砂の噴発を生じる恐れがあるため適切な 掘削制御を行うことが必要である.さらに，掘削部は前 進に伴い, 地山の影響を受け姿勢が変化し計画線からそ れる場合が考えられるため，シールドジャッキを用いて 計画線にそわせる方向制御を行うことも重要である.そ のために，以下の 5 項目について考慮した.

(1) カッターを回転させて土を切削しながらシール ドジャッキを伸ばすことにより掘削部本体を前進させ る.

(2) 切削した土砂は排土装置，ベルトコンベアを作 動させることにより後方のズリトロッコに積み込む. 
(3) 土質が軟らかく崩壊する 表一2 シールドジャッキ，スクレーパ起動条件 場合, チャンバー内のバルクヘ ッドに設けたレベルスイッチに よりチャンバー土砂レベルを検 出し, 土砂レベルに対応して排 土装置を ON-OFF させること により排土の制御を行ら.

(4) 土砂等による前進不能を 防止するためカッタートルク, ジャッキ推力等を常時監視し, 異常処理を行う.

(5) 方位角, 傾斜角, 回転角 をジャイロスコープ，アクセロ

\begin{tabular}{|c|c|c|c|c|}
\hline \multicolumn{2}{|c|}{ 条件 モート } & モードＩ & モード & モード \\
\hline $\begin{array}{l}2 \\
1 \\
1 \\
\text { N } \\
F\end{array}$ & OFF-伸び & $\begin{array}{l}\text { 1. カッタートルク } \begin{array}{l}\text { カッ } \\
\mathrm{kg} / \mathrm{cm}^{2}\end{array}\end{array}$ & $\begin{array}{l}\text { 1. 土砂レヘル計 } 1 \text { または } \\
3: \mathrm{OFF} \text { かつカッター } \\
\text { トルク } \leqq 100 \mathrm{~kg} / \mathrm{cm}^{2}\end{array}$ & $\begin{array}{l}\text { 1. カッタートルク } \mathrm{k} 100 \\
\mathrm{~kg} / \mathrm{cm}^{2} \\
\text { 2. 土砂レベル計 } 2: \mathrm{OFF}\end{array}$ \\
\hline $\begin{array}{l}\dot{v} \\
+ \\
* \\
*\end{array}$ & 伸び-OFF & $\begin{array}{l}\text { 2. } \begin{array}{l}\text { カッタートルク } \\
\mathrm{kg} / \mathrm{cm}^{2}\end{array}\end{array}$ & $\begin{array}{lrr}\text { 1. } & \text { 土砂レヘル計 } 1: \mathrm{ON} \\
2 . & \text { " } & 2: \mathrm{ON} \\
3 . & \text { " } & 3: \mathrm{ON}\end{array}$ & $\begin{array}{l}\text { 1. カッタートルク } \geqq 170 \\
\mathrm{~kg} / \mathrm{cm}^{2} \text { かつ土砂レへ } \\
\text { ル計 } 2: \mathrm{ON}\end{array}$ \\
\hline$\pi$ & OFF-ON & - & $\begin{array}{lrr}\text { 1. 土砂レヘル計 } 1: \text { ON } \\
\text { 2. } & \text { " } & 2: \mathrm{ON} \\
\text { 3. } & 3: \mathrm{ON} \\
\text { 4. カッタートルク } & \mathrm{kg} / \mathrm{cm}^{2} & \end{array}$ & $\begin{array}{l}\text { 1. 土砂レベル計 } 2: \mathrm{ON} \\
\text { 2. カッタートルク } \\
\mathrm{kg} / \mathrm{cm}^{2}\end{array}$ \\
\hline i & ON-OFF & - & $\begin{array}{l}\text { 1. 土砂レベル計 } 1 \text { または } \\
3: \mathrm{OFF} \text { かつカッター } \\
\text { トルク } \leqq 100 \mathrm{~kg} / \mathrm{cm}^{2}\end{array}$ & 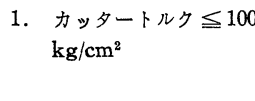 \\
\hline
\end{tabular}
メーターにより検出し, 前もって設定された計画姿勢 と常時比較監視を行う.

（b）掘進制御：掘進制御には，掘削制御と方向制御 の 2 つがある.

掘削制御については, シー ルド機のバルクヘッドに図一 6 に示すように各種センサー を設置し, 地盤条件により掘 削モードを I , II，IIIに分け， シールドジャッキ，スクレー パの起動条件を定め自動掘削 が可能なものとした．表一1

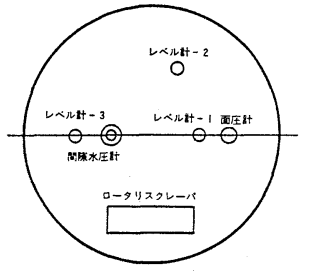

図一6 各種センサーの 設置状況 に掘削モード, 表一2 にシールドジャッキとスクレーパ の起動条件を示す. 図一7 は本システムの設定した掘削 制御の流れ図である。

一方, 方向制御については, トンネル坑内が狭いため にレーザー等による自動測量が不可能であることが判明 した. その結果，シールド機姿勢をジャイロスコープ， アクセロメーターにより計測し，掘進方向を定める方式 を採用した，すなわち，計画線に対応する姿勢目標値， 計画位置をキーボードから入力しその值と姿勢計測值を 比較するとともに，その差とあらかじめ設定されたしき い值の大小関係により図一8に示すようなジャッキパタ ーンから最適なものを選択し方向制御を行ら方法であ

表一1掘削制御

\begin{tabular}{|c|c|c|}
\hline 掘 削 & 対 象 地盤 & 内 \\
\hline I & $\begin{array}{l}\text { 自立性地盤 } \\
\text { (粘土, ンルト) }\end{array}$ & $\begin{array}{l}\text { ロータリースクレーパを常時回転し，チャン } \\
\text { バ内を空にするように土砂を取り込む. }\end{array}$ \\
\hline II & $\begin{array}{l}\text { 非自立性地盤 } \\
\text { (砂,砂質粘土, })\end{array}$ & $\begin{array}{l}\text { チャンバ内の土砂量をレベ計により監視 } \\
\text { し，一定量の土砂をチャンバ内に溜めるよ } \\
\text { にロータリスクレーパを間欠運転して土砂を } \\
\text { とりこむ. }\end{array}$ \\
\hline III & $\begin{array}{l}\text { 非自立性地盤 } \\
\text { (砂 碩) }\end{array}$ & 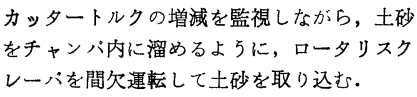 \\
\hline
\end{tabular}

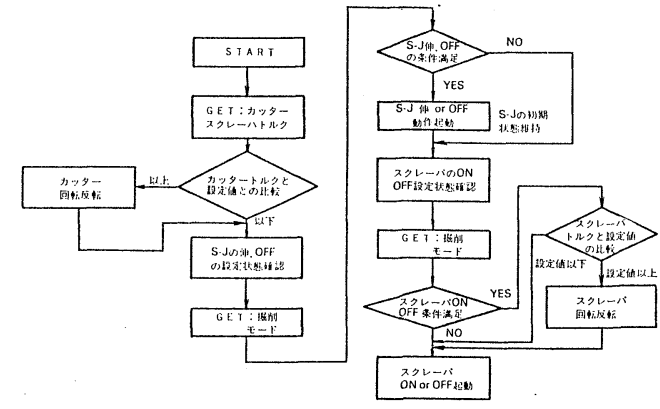

図一7留掘削制御のフローチャート

る. 方向制御の流れ図を図一9に，また掘進工程のディ スプレイ表示状況を 図一10 に示す.

\section{(3) ライニングエ程}

ライニング工程におけるアルゴリズムおよび工程制御 については, 以下に示すとおりである.

（a） アルゴリズム：本シールド機によるライニング は，まえがきでも述べたよらに，レジンモルタルの現場 打設方式を採用している.レジンモルタル材料は高粘度 であるため直接的な流量測定が困難であるとともに，型 枠は密閉された構造であるため容量以上の送給は型枠を

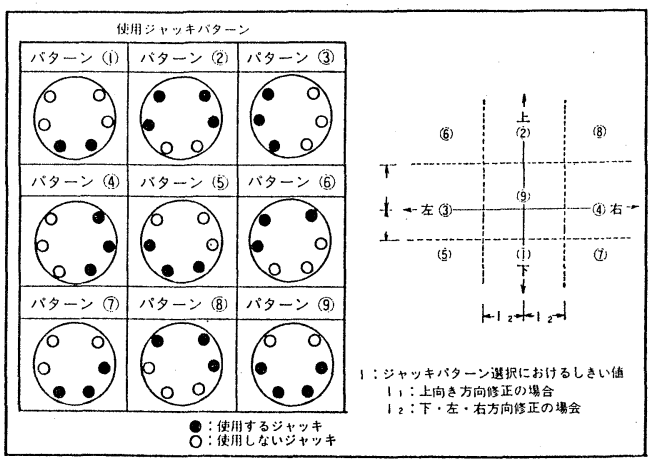

图一8 シールドジャッキ使用パターンによる方向制御 


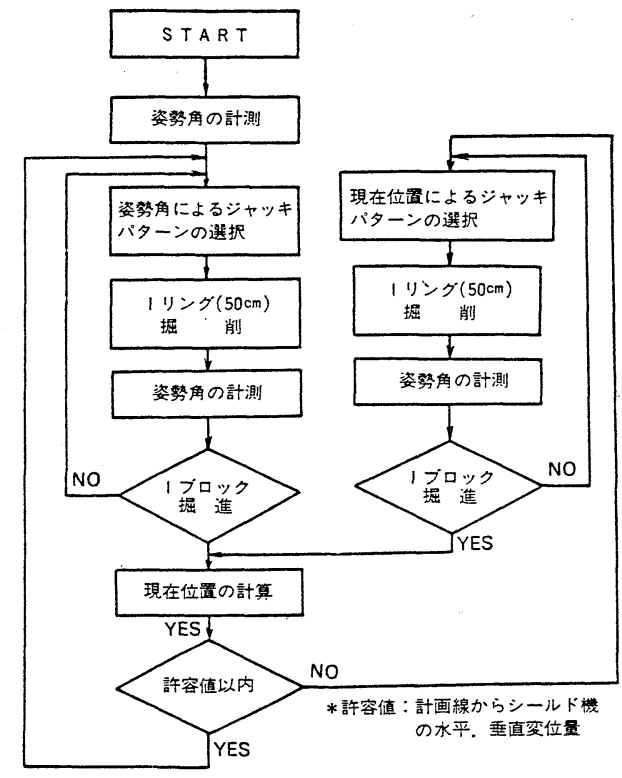

図一9 方向制御フローチャート

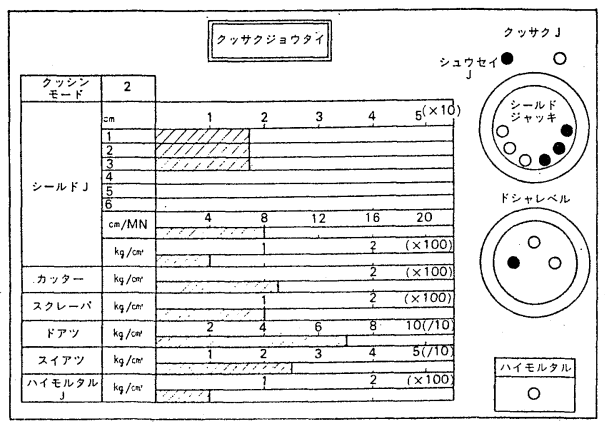

図一10琚削 状態

破損する恐れがある.そこで，アルゴリズムの作成にあ たっては，以下の 3 項目について考慮した。

(1) 打設開始タイミングはレジンモルタルの圧送を 開始して後, 混合打設機入口付近にレジンモルタルが 到達した時とする.

(2) 混合打設機を起動した後, レジンモルタル量と 硬化液を最適な混合となるように比例制御を行いなが ら混合し型枠内に送給する・レジンモルタル流量はタ ンクの重量変化により検出し, 硬化液の吐出量を変化 させる.

(3) 打設終了タイミングはレジンモルタルの型枠内 のレベルに到達した時とする.

（b） ライニング制御：信頼性の高いレジンモルタル ライニングでトンネルを築造するために，レジンモルタ ルと硬化液を一定の比率で混合する必要がある。レジン モルタルの送給量はタンク重量の変化量で検出し, 送給 量に応じて硬化液量は一定の比率になるように比例制御
が行われるが，そのためにフィードバック制御方法を採 用している. 充填検知制御では, 充填検知センサーが誤 充填の検知を行わないように, 単位時間当たりの温度降 下率とその継続時間のプログラム上の制御值を最適なも のに設定した．図一11 に打設に扝ける流れ図を，図一 12 にディスプレイ表示状況を示す.

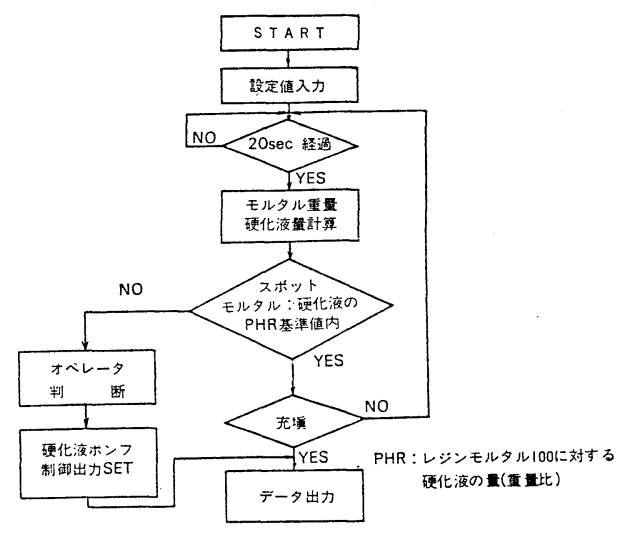

図一11 打設フローチャート

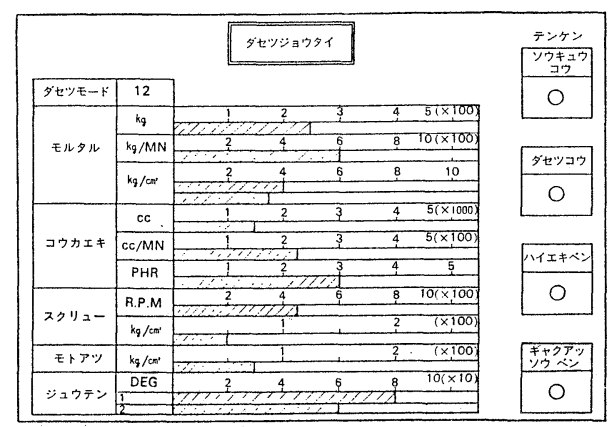

図一12 打設状態

\section{(4) 坑内運搬車走行}

坑内運搬車走行工程におけるアルゴリズムと制御につ いては以下のとおりである.

（a） アルゴリズム：狭いトンネル坑内には, 制御ケ ーブル，風管等が設置されており空間が制約されている ため坑内運搬車が無軌道で自動走行するには適切な制御 が必要である. 次の 2 項目について考慮した。

(1) 坑内運搬車制御方式は，センター装置からの指 令により発進させた後, 運搬車自身のローカル制御に より速度制御，ローリング制御を行いながら停止位置 近くまで進んで減速した後, センター装置からの停止 指令により停止する.

(2) 停止位置に対するオーバーランを防止するため 距離計による停止位置の検出を行う.

（b）坑内運搬車走行制御：坑内運搬車の走行には, ローリング角を操蛇機構により一定の角度内に抑制する 
とともに，無線により信号伝送を行い，無線の届かない 区間 $(15 \mathrm{~m})$ 以上では，運搬車のローカル制御により速 度, 走行制御を行う機構を採用した。

自動走行の流れ図を 図一13 にディスプレイの表示状 態を図一14 に示寸.

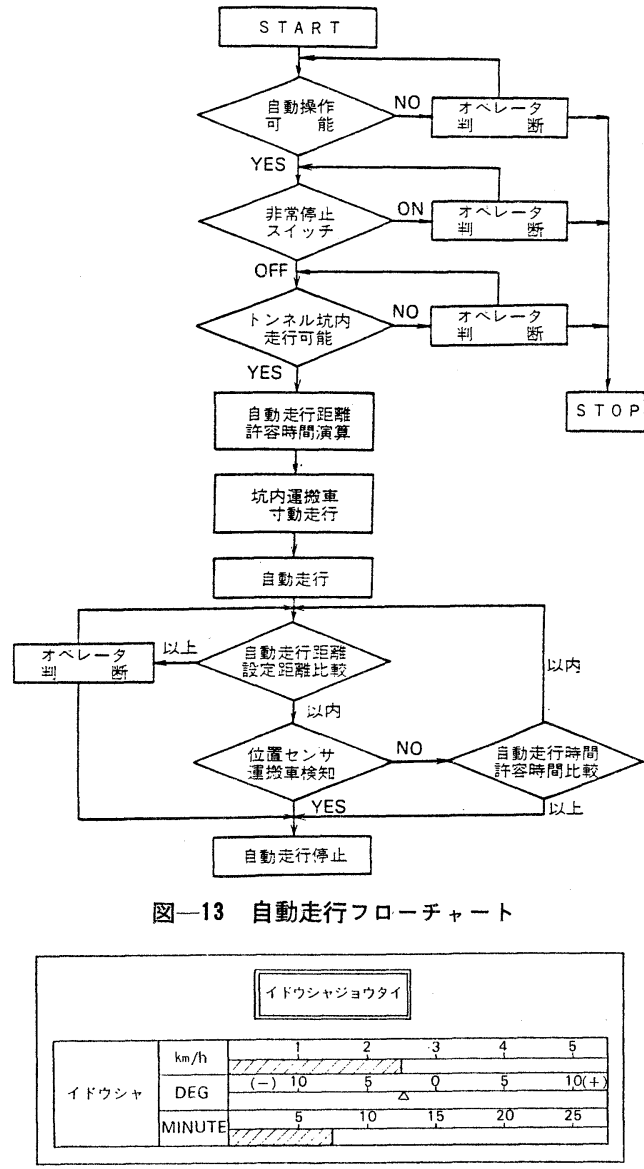

図-14 移動軒状態

\section{4.試験エ事によるシステムの検証}

本システムで開発した各種の機能を実際の現場で検証

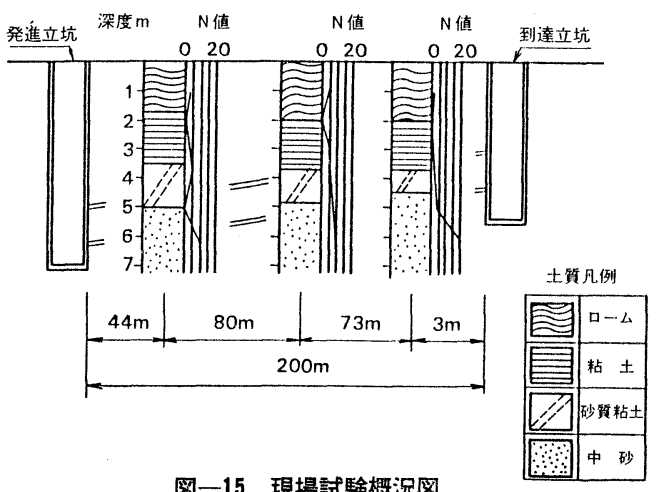

するために, 昭和 58 年 4 月より 59 年 3 月にわたって, $200 \mathrm{~m}$ の掘進工事を行い本システムの機能確認を行った

\section{（1）工事試験概要}

本試験工事の概要を図一15に試験条件を表一3に示す 当該試験工事区間は, $N$ 值 5 以下の涌水砂質，粘性 土であり非常に軟弱な地盤である.このような地盤での 掘進は初めての試みであり，各種制御技術の機能確認を 行うには最適な地盤条件であると言える.

表一3 試験条件

\begin{tabular}{|c|c|c|c|}
\hline 項 & & 目 & 件 \\
\hline & 進 & 長 & $200 \mathrm{~m}$ \\
\hline \multirow{2}{*}{ 線 } & \multirow{2}{*}{\multicolumn{2}{|c|}{ 开 }} & 曲率半径 $R=200 \mathrm{~m}$ \\
\hline & & & 縦断勾配 $0.5,1.0,2.0 \%$ \\
\hline 地 & & 艋 & 湧水砂質，粘性土 \\
\hline 地 - & 下 水 & 压 & $0.3 \mathrm{~kg} / \mathrm{cm}^{2}$ \\
\hline
\end{tabular}

（2）掘進技術

（a）掘削制御：掘削モードIにおお方動掘削制御 の状況を 図一16 に示す.カッターおよびシールドジャ ッキはロータリースクレーパーのストップ時には負荷が かかるとともに，ロータリースクレーパーの作動時には カッターおよびシールドジャッキの負荷は軽減されてい るのが分かる．掘削モードIにおおる掘削，土砂取り込 み装置が土砂レベル計の $\mathrm{ON}-\mathrm{OFF}$ により間欠運転をし ており掘削制御が非常にうまく行われた．排土量の管理 については，1リングごとの掘削土量をロードセルで測 定した結果，シールドジャッキを $50 \mathrm{~cm}$ 伸ばした時の 理論的排土量 $1.40 \mathrm{t}$ に対して平均值で $1.37 \mathrm{t}$ でありオ ーバーカットはなく十分な排土管理制御が行われた.

（b）方向制御：あらかじめ設定された計画線にシー ルド機が沿うように，方向制御がシールドジャッキの自 動選択により行われる. 図一17 に $200 \mathrm{~m}$ の掘進軌跡と 計画線の比較を示す。

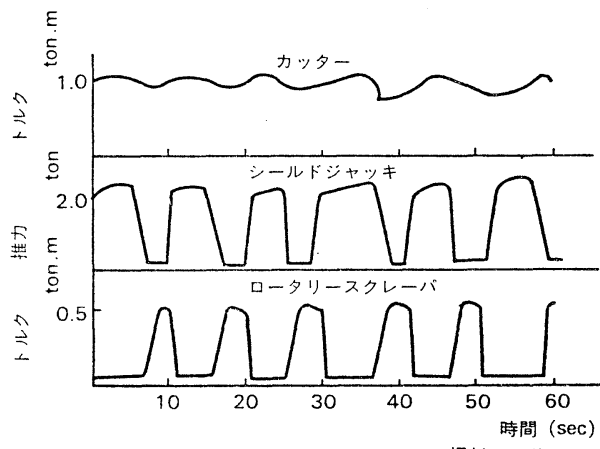

掘削モードII 
掘進当初は，計画線の設定值誤入力により，平面線形 は急激な曲率半径 $(R=100 \mathrm{~m}$ 以下) を描くこととなった。 その後は正確に目標である $200 R$ を描いていった様子が よくわかる. 後半では, 非常に軟弱な地盤での掘進のた めマシンの横之り現象が生じ, 計画線から大幅にそれる 結果 (約 $60 \mathrm{~cm}$ ) となった. 今後の検討課題の 1 つである.

縦断勾配においては，地盤が軟弱のため当初計画した 縱断勾配が得られず，地盤により計画線の值を入力する にあたり補正した数值をインプットすることと，しきい 值の幅をせげめる必要があることが判明した．曲率半径 $(R=200 \mathrm{~m})$ を描くための方向制御結果について 図一18, 使用ジャッキパターンによる制御結果について 図一19 に示す.これらにより左右カーブの目標值に対して方向 制御を行っていることが分かり，十分な方向制御機能を 有していることが確認された.

\section{（3）ライニング技術}

ライニング制御については, レジンモルタル量に比例 した硬化液量をレボルーションコントローラーの自動遠

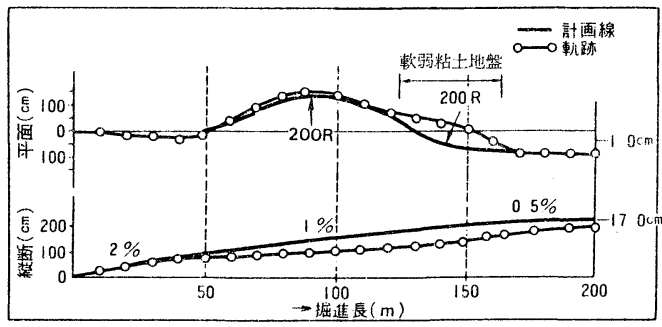

図一17掘進軌 跡

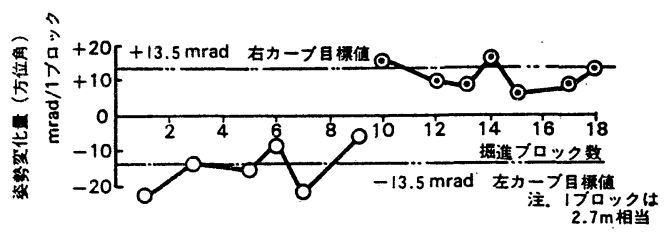

図一18 曲線部における方向制御結果（その1）

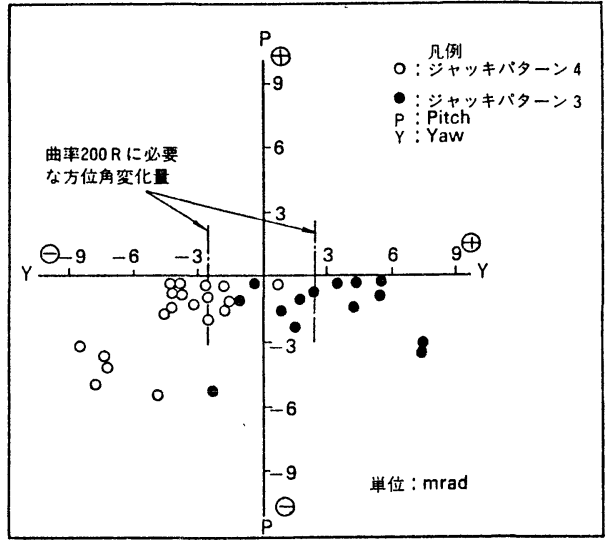

図一19 曲線部における方向制御結果（その 2）
隔制御により変化させており，混合比を目標值 $3.0 \pm 1.0$ PHR (重量比) の範囲に押さえる制御を行うものである. 図一20 に硬化液制御状況を図一21に 1 リング打設にお ける各スポットの PHR の状況を示す．これらの結果に より, 硬化液量は $3.0 \pm 1.0$ PHR の範囲に制御されて おり十分信頼性の高いレジントンネルが筑造されてい る. また充填検知制御においては，単位時間当たりの温 度降下率とその継続時間をそれぞれ $0,2^{\circ} \mathrm{C} ， 3$ 秒とする ことにより電気的ノイズ等による誤充填を防止すること ができた.

\section{（4）坑内運搬車走行技術}

無軌道のレジントンネルを坑内運搬車が走行した状況

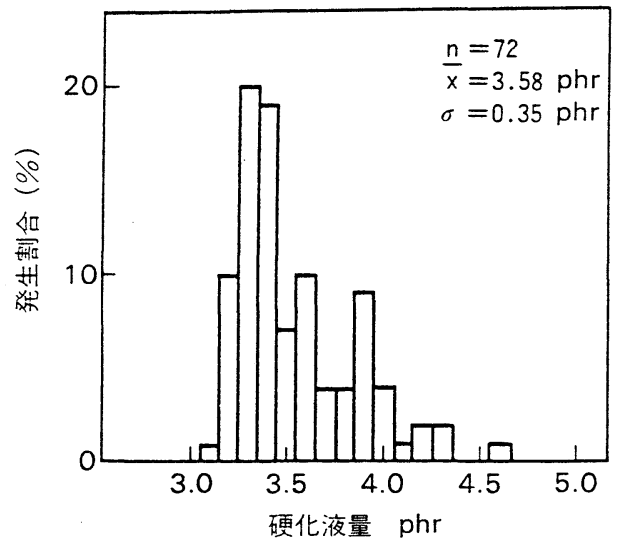

図一20 硬化液量制御状況

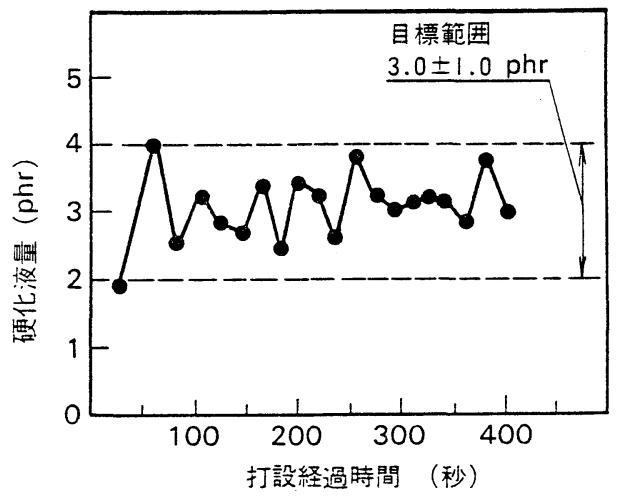

図一21 硬化液量の制御変化

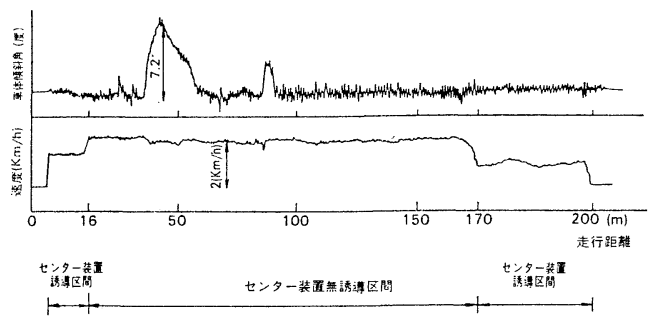

図一22 走行制御状況 


\section{を図一22 に示す.}

走行制御状況においては, 許容車体傾斜角 10 度を下 回るもので操蛇機構は十分機能している.さらに一定位 置で速度自動切り替えがなされているとともに定速度制 御が行われていることも確認された.

\section{（5） システムの信頼性}

各工程を自動制御するにあたり，多数のセンサー, ア クチュエーターを苛酷な環境下で使用するためにシステ ムの信頼性が重要である. 図一23 に掘進試験工事中に おける装置類の調整状況を示す.

\begin{tabular}{|c|c|c|c|c|c|c|c|}
\hline 点换項目 & MC P 部 & L部 & 玾内運活車 & 打段機 & \multicolumn{2}{|c|}{ 抹料ブラント } & 斗の他 \\
\hline 亚合 $(\%)$ & 11 & 32 & & 24 & 15 & 3 & 15 \\
\hline
\end{tabular}

\section{図一22 点検状況}

掘削，排土工程における装置類の調整は少ないが，ラ イニング工程に必要な型枠機構, 打設機系統において は, 高粘性のレジンモルタルと接触するために, レジン 洩れ，硬化状のレジン破片のつまりによる開閉弁の不調 による調整が発生した. 耐久性をもち保守, 点検の容易 な装置にする必要があることが判明した.

\section{5. 評価}

M-2 工法による集中自動制御システムは，曲線区間 をもつ長距離のトンネル自動筑造工法の確立を目指した ものである. そのために, シールド機, 坑内運搬車等を センターのコンピューターにより制御し, 掘削, ライニ ング, 掘削土・ライニング材料等のトンネル坑内の搬出 入作業の無人化を図った. 実地盤におけるレジントンネ ル築造試験の結果, 本集中制御システムについて以下の ことが言える.

(1) トンネル坑内での作業では，遠隔自動制御によ り行えるため, 狭いトンネル坑内での危険な作業が無 くなり, 小人数で安全な作業が可能である.

(2) オペレーターの判断による操作とは異なり，コ ンピューターにより制御を行っているため, 多種多様 な装置類の状況が 常時 コンピューターにより監視さ れ,オペレーターの作業負担が大幅に軽減されてお
り，ワンマンコントロールが可能である.

(3) 地盤状況やレジンモルタルの送給特性の変化に 追随可能なように, コンピューターにより制御してい るため施工品質の向上が図れる.

(4) 従来のヒューム管推進工法とは異なり, 小口径 のシールド機による自動掘進作業がライニング工程を 含めて可能であることは, 大断面のシールド機におい ても本システムの制御技術の適用によりトンネル坑内 作業の自動化が可能である.

\section{あとがき}

コンピューター制御によるシールド工法の自動化の開 発にあたり，シールド機の設計からソフトウエアを含め たトータルシステムの技術開発は一般のシールド工法で はあまりなされておらず，本論文で述べたシステムの開 発にあたり非常に労力と時間を要したところである.

今後, 建設業においては, 労働市場の高齢化, 高学歷 化および作業環境の悪化に対処するため,メカトロニク ス技術の導入が進展してくるものと思われ，本システム の制御技術が意味を持つものと予想される.

本システムは, 高度にメカトロニクス化されている が，何分初めての試みであるため制御状況を確認するた め多様な装置類を装備しており，また高価なレジン材料 を使用しているため従来の工法と比較して若干割高にな っている.これからは，施工スピード，信頼性の向上， 低廉なライニング材料の開発，システムの簡素化が重要 な課題である.

最後に M-2 システムの開発にあたり長年にわたって 助言を頂いた茨城電気通信研究所の福富所長, 小島線路 部長，ならびに内田統括役に深謝するものであります。

\section{参考文献}

1）奈良慎一・杉本禎男：小断面シールド工法 $(\mathrm{M}-2)$ に掠け る集中制御方法の検討, 土木学会年次学術講演会概要集, 1982 年.

2）鶴田秀典・杉本禎男：コンピュータ制御によるレジント ンネル自動築造工法, 土木学会 第 8 回電算機利用に関す るシンポジウム講演概要集, 1983 年.

3）鶴田秀典・杉本禎男・高塚外志夫・阿南修平：レジント ンネル自動築造技術の開発, 土木学会誌 Vol. 69, No. 4, pp. $2 \sim 8,1984$ 年 4 月.

(1984.11.26 · 受付)

\section{ご案内○} 土木学会論文集編集委員会第VI小委員会

『土木学会論文集・第VI部門』は年 2 回 ( 3 月，9月）の発行です. 別揭の投稿要項等をご覧のうえ，多数の 論文を扮寄せ下さい.

なお，不詳点等は事務局編集課（電話０3-355-3441 番, 内線 156）あてお願いします. 